\title{
Sickle cell retinopathy: A literature review
}

\author{
Marina Viegas Moura Rezende Ribeiro ${ }^{1}$, João Vitor de Omena Jucáa ${ }^{*}$, Anna Luyza Correia dos Santos Alves², \\ Caio Victor Oliveira Ferreira ${ }^{2}$, Fabiano Timbó Barbosa ${ }^{3}$, Êurica Adélia Nogueira Ribeiro ${ }^{4}$ \\ ${ }^{1}$ Ophthalmologist, MSc in Health Science, Professor at Universidade Tiradentes, Maceió, AL, Brazil \\ ${ }^{2}$ Medical Student, Universidade Tiradentes, Maceió, AL, Brazil \\ ${ }^{3} \mathrm{PhD}$ in Health Science, Professor at Universidade Tiradentes, Maceió, AL, Brazil \\ ${ }^{4} \mathrm{PhD}$ in Pharmacology, Professor at Universidade Federal de Alagoas, Health Science Graduate Program, Maceió, AL, Brazil
}

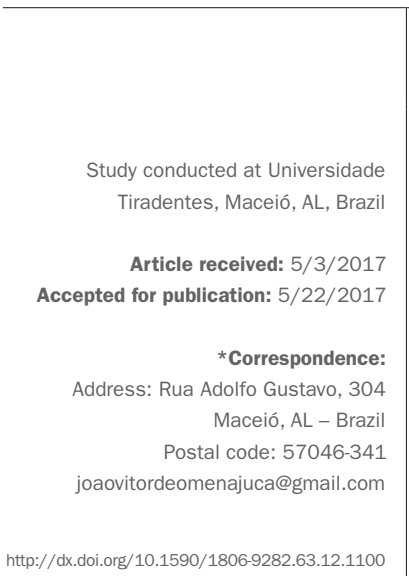

\section{SUMMARY}

Hemoglobinopathies are a group of hereditary diseases that cause quantitative or qualitative changes in the shape, function or synthesis of hemoglobin. One of the most common is sickle cell anemia, which, due to sickling of erythrocytes, causes vaso-occlusive phenomena. Among the possible ocular manifestations, the most representative is retinopathy, which can lead to blindness if left untreated. Therefore, periodic ophthalmologic monitoring of these patients is important for early diagnosis and adequate therapeutic management, which can be done localy by treating the lesions in the eyes, or systemically.

Keywords: retinal diseases, anemia, sickle cell, review, hemoglobinopathies.

\section{INTRODUCTION}

Sickle cell disease is the most frequent and disabling chronic hemolytic anemia in our country. Sickle cell anemia is characterized by the production of abnormal hemoglobins that deform and stiffen red blood cells, causing increased blood viscosity and microcirculation occlusion to varying degrees. ${ }^{1}$ These hemoglobins are insoluble at low oxygen concentrations, and tend to crystallize. ${ }^{2}$ Sickle hemoglobin (HbS) is characterized by a mutation in the $\beta$-globin gene involving a single nucleotide $(\mathrm{G} \underline{\mathrm{AG}} \rightarrow \mathrm{G} \underline{\mathrm{T}})$ which replaces glutamine with valine in sixth amino acid position. ${ }^{3,4}$ The most common genotypes are homozygous (SS), heterozygous or sickle cell trait (SA), hemoglobin C trait (SC), hemoglobin D trait (SD), and thalassemia genotype (S-Thal)., ${ }^{1,5}$

The World Health Organization (WHO) estimates that more than $5 \%$ of the world population has some type of hemoglobinopathy. The estimate of new cases in Brazil is 700 to 1,000 per year, with a prevalence of over 2 million carriers of the HbS gene. ${ }^{9}$ Sickle cell retinopathy, the subject of this study, develops in up to $42 \%$ of sickle cell individuals in the second decade of life..$^{10}$

The systemic manifestations of sickle cell disease may be neurological, ophthalmologic, cardiac, pulmonary, gastrointestinal/hepatobiliary, renal/genitourinary, splenic, muscular/skeletal, and growth and developmental disorders. ${ }^{11}$ They are more severe in homozygotes for cell disease (SS) than in heterozygotes with sickle hemoglobin $\mathrm{C}(\mathrm{SC})$, and yet visual loss due to proliferative retinopathy is more common in the latter. ${ }^{6}$

Sickle cell retinopathy is not frequently reported in the literature, and studies in this regard are very old. This was one of the motivations for our study, which seeks to gather the information known and thereby clarify the progression of the disease, its diagnosis and treatment.

\section{Method}

We searched the PubMed (US National Library of Medicine - National Institutes of Health) database using the following keywords: "retinopathy," "sickle cell," "sickle cell disease" and "sickle cell anaemia."

\section{Ocular manifestations}

Ocular manifestations of sickle cell anemia include orbital, conjunctival, uveal, papillary, and especially retinal changes. ${ }^{5,7,12}$ Retinal changes characterize sickle cell retinopathy, which may be non-proliferative or proliferative and is divided into five stages. $1,10,12,13$

Among the forms of sickle cell anemia, SS patients present a more severe systemic clinical picture than those with type SC. On the other hand, occlusive ocular effects are more predominant in SC patients, who present only moderate anemia and higher blood viscosity. ${ }^{5}$ These vasoocclusions occur primarily in younger people, and are first 
observed at the periphery of the retina, resulting in unperfused and presumably ischemic areas. Retinal neovessels, in turn, tend to develop in these areas, but not necessarily. ${ }^{14}$ Individuals with SCD as well as sickle cell trait (AS) are at increased risk of developing increased intraocular pressure when they present with hyphema (bleeding in the anterior chamber of the eye). ${ }^{12}$ Low fetal hemoglobin (HbF) is generally associated with increased intravascular sickling and is responsible for several vaso-occlusive complications in homozygous SS. ${ }^{15}$ In addition, Roy et al. associated proliferative retinopathy with low levels of $\mathrm{HbF}^{16}$

Another possible change cited by Ballas et al. ${ }^{11}$ is glaucoma, due to high ocular pressure caused by clogging of the trabecular meshwork and the inflow of aqueous humor. Vaso-occlusion leads to optic nerve damage, causing visual impairment even before the occurrence of retinal changes. ${ }^{17}$

Non-proliferative retinopathy can occur with small intra-retinal hemorrhages, possibly due to ischemic vessel wall necrosis, called salmon patches; the bleeding then becomes yellow and then white, disappearing without a trace. There may also be hyperpigmented lesions in deeper or sub-retinal hemorrhages, called black sunbursts (Figure 2). ${ }^{12}$ Maculopathy occurs as a result of chronic changes in the perifoveal capillary network. ${ }^{8}$

According to David et al., ${ }^{1}$ there was macular change in $14.4 \%$ of the patients. However, Clarkson found $4.6 \%$ of this same type of lesion. Both found higher prevalence in the SS type.

Although proliferative retinopathy has the same genesis as nonproliferative retinopathy, their progression differs. It was divided by Goldberg in five stages, ${ }^{12,18}$ correlating them with their order of appearance: Stage I is characterized by definitive arteriolar occlusion, with consequent retinal hypoxia and rearrangement of adjacent capillaries. In the next stage (stage II), the budding of new vessels begins, with possible dilatation, aiming to join the vascular and avascular retina. In stage III, under the action of angiogenic events, pre-retinal neovascularization occurs, forming the so-called retinal sea fans. ${ }^{12}$ These new vessels develop from arteriovenous loops or crossings, and often undergo self-infarctions probably caused by the unusual characteristics of the flow. The new vessels are fragile, immature and adherent to the vitreous. This facilitates the occurrence of vitreous hemorrhage and characterizes stage IV of proliferative retinopathy in sickle cell disease. When bleeding reaches the visual axis, it causes scotomas and amaurosis. The repetition of these hemorrhagic phenomena leads to rupture, retinal detachment and vision loss (stage $V$ ), the final stage of sickle cell proliferative retinopathy. ${ }^{12}$
Sickle cell retinopathy develops in up to $42 \%$ of sickle cell individuals in the second decade of life. ${ }^{10}$ Vascular tortuosity is the most common finding (Figure 1), reported by the authors in about $30-50 \%$ of cases. ${ }^{5,19,20}$ Cury et al. ${ }^{3}$ found a prevalence of $19.6 \%$, a result that may be justified by the fact that the study was conducted in children only. In addition, about $10-20 \%$ of patients will develop proliferative retinopathy, ${ }^{8}$ mainly in the fourth and fifth decades of life. ${ }^{21}$

\section{Diagnosis}

In the early stages, the disease is asymptomatic, and meticulous ophthalmologic monitoring should be performed. ${ }^{8}$ Diagnosis is made by retinography and fluorescein angiography in cases with fundoscopic alterations, as well as measurement of visual acuity and intraocular pressure. ${ }^{5,7,8,13}$

\section{TREATMENT}

Treatment is performed in different ways, including diathermy, cryotherapy and argon or xenon photocoagulation.

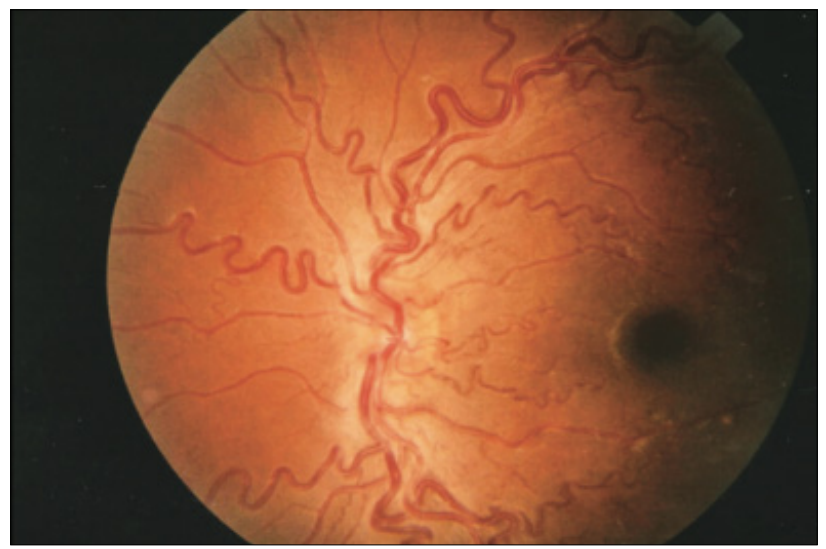

FIGURE 1 Increased vascular tortuosity.



FIGURE 2 "Black sunburst."1 

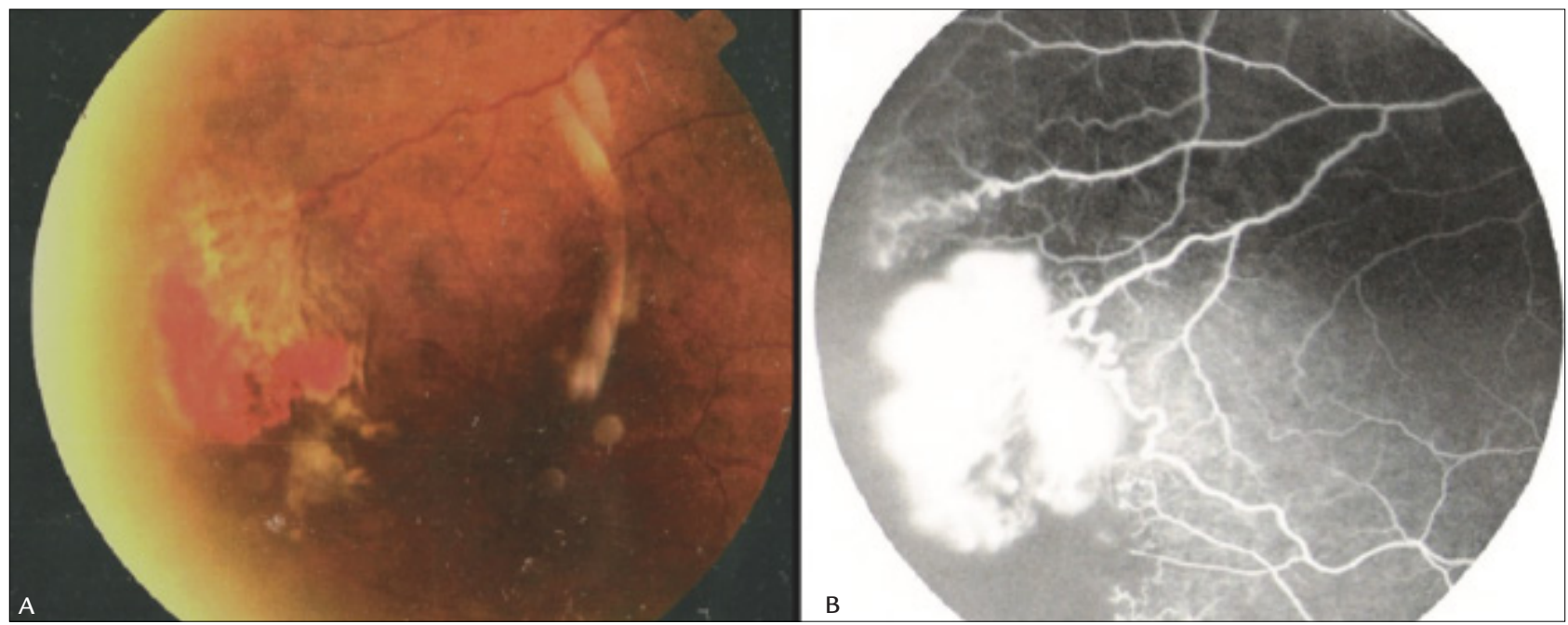

FIGURE 3 A. "Sea fan." B. Angiographic appearance of the "sea fan."

The latter is widely used to treat the typical stage III lesion (sea fan) of proliferative retinopathy. However, patients in stages I and II are not treated, since the treatment of ischemic lesions in these stages does not prevent the formation of sea fan (Figure 3), and most patients do not develop the complication. ${ }^{8,22}$ There is also surgical treatment, which is indicated for complications of proliferative retinopathy, such as retinal detachment and vitreous hemorrhage. ${ }^{8,23}$

According to Clarkson, ${ }^{24} 1992$, prophylactic photocoagulation may play a role in the treatment of selected patients with SC proliferative sickle cell retinopathy, but none of the studies reported to date have demonstrated that this treatment improves long-term visual outcome compared to natural progression, as documented in the present study. The similar visual results in the eyes analyzed in our study during the natural progression of the disease compared to those treated with photocoagulation should not be unexpected, because there is a greater predilection for spontaneous involution or neovascular tissue infarction in SC disease as opposed to neovascularization that develops in other vascular diseases of the retina. Clarkson ${ }^{24}$ suggests that a multicenter controlled clinical trial designed to study eyes at greater risk should be considered. There is, however, no clear definition of the risk factors leading to these advanced stages, and the value of treatment is uncertain. ${ }^{24}$

In addition, since ocular disorders of retinopathy result from a systemic pathological process, prevention can be done with appropriate treatment of anemia using several emerging approaches, such as: ${ }^{8,25}$ increase in fetal hemoglobin using hydroxyurea, omega- 3 and erythropoietin, 2-deoxy-5-azacytidine; erythrocyte hydration (clotrimazole, magnesium pidolate); anti-inflammatory and anti-adhesive drugs (anti-adhesive antibodies, anti-integrin antibodies, anti-Willebrand factor, sulfasalazine, statins); antioxidant therapy (glutamine, deferiprone); antithrombotic agents (heparin, ticlopidine, warfarin); vasodilatation (nitric oxide, arginine, Flocor); decrease in hemoglobin S by transfusion and apheresis; transplantation of hematopoietic cells and gene therapy.

\section{Conclusion}

Considering that sickle cell retinopathy is a complication that causes $42 \%$ of blindness in the affected patients, we point out the importance of new studies on the subject, since there is a gap especially in randomized clinical trials. The importance of our review is to draw attention to the need for periodic ophthalmologic monitoring in patients with anemia since childhood, aiming at prevention, diagnosis and early treatment of the disease.

\section{Resumo}

Retinopatia da doença falciforme: revisão da literatura

As hemoglobinopatias são um grupo de doenças hereditárias que causam alterações quantitativas ou qualitativas no formato, na função ou na síntese de hemoglobinas. Uma das mais comuns é a anemia falciforme, cuja patogenia é a foicização das hemácias, causando fenômenos vaso-oclusivos. Dentre as manifestações oculares possíveis, a mais representativa é a retinopatia, que pode levar à cegueira caso não seja tratada. Por isso, é importante que haja o acompanhamento oftalmológico perió- 
dico desses pacientes, a fim de obter diagnóstico precoce e abordagem terapêutica adequada. Esta última pode ser de maneira direta, com tratamento das lesões oculares, ou de forma sistêmica.

Palavras-chave: doenças retinianas, anemia falciforme, revisão, hemoglobinopatias.

\section{RefERENCES}

1. David RC, Moraes Júnior HV, Rodrigues MPM. Alterações oculares e eletrorretinográficas na doença falciforme. Arq Bras Oftalmol. 2011; 74(3):190-4.

2. Lima CS, Rocha EM, Silva NM, Sonatti MF, Costa FF, Saad ST. Risk factors for conjunctival and retinal vessel alterations in sickle cell disease. Acta Ophthalmol Scand. 2006; 84(2):234-41.

3. Cury D, Boa-Sorte N, Lyra IM, Zanette AD, Lima HC, Castro BG, et al. Ocular lesions in sickle cell disease patients from Bahia, Brazil. Rev Bras Oftalmol. 2010; 69(4):259-63.

4. Oliveira DCA, Carvalho MO, Nascimento VM, Villas-Bôas FS, Galvão-Castro B, Gonçalves MS. Sickle cell disease retinopathy: characterization among pediatric and teenage patients from northeastern Brazil. Rev Bras Hematol Hemoter. 2014; 36(5):340-4.

5. Garcia CAA, Fernandes MZ, Uchôa UBC, Cavalcante BM, Uchôa RAC Achados fundoscópicos em crianças portadoras de anemia falciforme no estado do Rio Grande do Norte. Arq Bras Oftalmol. 2002; 65(6):615-8.

6. Penman AD, Talbot JF, Chuang EL, Thomas P, Serjeant GR, Bird AC. New classification of peripheral retinal vascular changes in sickle cell disease. $\mathrm{Br}$ J Ophthalmol. 1994; 78(9):681-9.

7. Santos AM, Faro GPA, Amaral MVM, Mendonça CQ, Leal BC, Cipolotti R. Alterações retinianas em jovens portadores de anemia falciforme (hemoglobinopatias) em hospital universitário no nordeste do Brasil. Arq Bras Oftalmol. 2012; 75(5):313-5.

8. Bonanomi MTBC, Lavezzo MM. Sickle cell retinopathy: diagnosis and treatment. Arq Bras Oftalmol. 2013; 76(5):320-7.

9. Almeida Sobrinho EF, Saraiva JCP, Silva JN, Silva APS, Lima RC. Manifestações retinianas em pacientes portadores de anemia de células falciformes. Rev Bras Oftalmol. 2011; 70(5):284-9.
10. Melo MB. An eye on sickle cell retinopathy. Rev Bras Hematol Hemoter. 2014; 36(5):319-21.

11. Ballas SK, Lieff S, Benjamin LJ, Dampier CD, Heeney MM, Hoppe C, et al.; Investigators, Comprehensive Sickle Cell Centers. Definitions of the phenotypic manifestations of sickle cell disease. Am J Hematol. 2010; 85(1):6-13

12. Vilela RQB, Bandeira DM, Silva MAE. Alterações oculares nas doenças falciformes. Rev Bras Hematol Hemoter. 2007; 29(3):285-7.

13. Freitas LGA, Isaac DLC, Tannure WT, Lima EVS, Abud MV, Tavares RS, et al. Alterações retinianas apresentadas em pacientes portadores de hemoglobinopatia falciforme atendidos em um Serviço Universitário de Oftalmologia. Arq Bras Oftalmol. 2011; 74(5):335-7.

14. Cao J, Mathews MK, McLeod DS, Merges C, Hjelmeland LM, Lutty GA Angiogenic factors in human proliferative sickle cell retinopathy. $\mathrm{Br} \mathrm{J}$ Ophthalmol. 1999; 83(7):838-46.

15. Talbot JF, Bird AL, Maude GH, Acheson RW, Moriarty BJ, Serjeant GR. Sickle cell retinopathy in Jamaican children: further observations from a cohort study. Br J Ophthalmol. 1988; 72(10):727-32.

16. Roy MS, Rodgers GP, Noguchi CT, Schechter AN. Retinal signs in sickle cell anaemia. Eye (Lond). 1990; 4(Pt 6):862-4.

17. Silva MC, Leite MM, Vilela RQB, Santos MJ, Santos AMC. Anemia falciforme e glaucoma: estudo de caso-controle. Rev Bras Oftalmol. 2004 63(3):208-12.

18. Goldberg MF. Classification and pathogenesis of proliferative sickle retinopathy. Am J Ophthalmol. 1971; 71(3):649-65.

19. Moraes Júnior HV, Araújo PCM, Brasil OFM, Oliveira MVF, Cerqueira V Turchetti R. Achados oculares em doença falciforme. Rev Bras Oftal. 2004; 63(5-6):299-302.

20. Gonçalves JCM, Braga JAP, Nione AS, Simoceli RA, Yamamoto M. Retinopatia falciforme em crianças. Arq Bras Oftalmol. 1990; 53(4):158-61.

21. Liem RI, Calamaras DM, Chhabra MS, Files B, Minniti CP, Thompson AA Sudden-onset blindness in sickle cell disease due to retinal artery occlusion. Pediatr Blood Cancer. 2008; 50(3):624-7.

22. El-Ghamrawy MK, El Behairy HF, El Menshawy A, Awad SA, Ismail A, Gabal MS. Ocular manifestations in Egyptian children and young adults with sickle cell disease. Indian J Hematol Blood Transfus. 2014; 30(4):275-80.

23. Condon PI, Serjeant GR. Photocoagulation and diathermy in the treatment of proliferative sickle retinopathy. Br J Ophthalmol. 1974; 58(7):650-62.

24. Clarkson JG. The ocular manifestations of sickle-cell disease: a prevalence and natural history study. Trans Am Ophthamology Soc. 1992; 90:481-504.

25. Bunn HF. Pathogenesis and treatment of sickle cell disease. N Engl J Med. 1997; 337(11):762-9. 